\title{
Pemberdayaan Kelompok Usaha Pengolahan Ikan Desa Pasar Banggi, Kecamatan Rembang, dalam Upaya Meningkatkan Kualitas Produksi Olahan Ikan Asap \\ Rikah $^{1}$, Gostsa Khusnun Naufal ${ }^{2}$, Agustina Widodo $^{1}$ \\ ${ }^{1}$ STIE YPPI Rembang; ${ }^{2}$ UPGRIS Semarang \\ Rickah83@gmail.com
}

Key word:

Smoked fish;

fish smokers;

Community

Partnership

Program;

production

quality

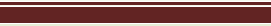

\section{Abstract}

Smoked fish processing business in Pasar Banggi Village, Rembang District, Rembang Regency with Karya Mina smoked fish processing partner. The fish fogging process is done by first drying the fish in an open area. Pasar Banggi Village is a village located around the tourist area and is a center for souvenirs from marine products, one of which is smoked fish. The purpose of the Community Partnership Program (PKM) is to increase community income through increased quality and quantity of smoked fish production. The method used in the Community Partnership Program (PKM) is through socialization / counseling, management training, simple financial accounting and online marketing and business assistance. The results of the Community Partnership Program (PKM) include 1) an increase in the role of smoked fish business group members and business networks, 2) the realization of environmentally friendly smoked fish processing equipment / machines whose goal is to minimize air pollution caused by traditional / conventional fumigation of fish and maintain the quality and hygiene of processed fish products in the form of smoked fish.

\section{Abstrak}

\section{Kata Kunci}

Ikan asap; mesin pengasap ikan;

Program

Kemitraan

Masyarakat; kualitas produksi
Usaha pengolahan ikan asap di Desa Pasar Banggi, Kecamatan Rembang, Kabupaten Rembang dengan mitra kelompok pengolah ikan asap Karya Mina. Proses pengasapan ikan dilakukan dengan penjemuran ikan terlebih dahulu di area terbuka. Desa Pasar Banggi merupakan Desa yang berada disekitar kawasan wisata dan merupakan sentra oleh-oleh hasil produksi laut yang salah satunya berupa ikan asap. Tujuan dari Program Kemitraan Masyarakat (PKM) ini adalah untuk meningkatkan pendapatan masyarakat melalui kualitas dan kuantitas produksi ikan asap yang meningkat. Metode yang dilakukan dalam Program Kemitraan Masyarakat (PKM) ini adalah dengan sosialisasi/penyuluhan, pelatihan manajemen, pembukuan keuangan sederhana dan pemasaran online serta pendampingan usaha. Hasil Program Kemitraan Masyarakat $(P K M)$ ini diantaranya 1) adanya peningkatan peran anggota kelompok usaha ikan asap dan jejaring usaha, 2) terealisasinya alat/mesin pengolah ikan asap yang ramah lingkungan yang tujuannya dapat meminimalisir polusi udara yang disebabkan oleh pengasapan ikan secara tradisional/konvensional serta menjaga kualitas dan higienitas dari produk olahan ikan yang berupa ikan asap. 


\section{PENDAHULUAN}

\section{Pertumbuhan Ekonomi kreatif}

Pelaku usaha mikro kecil dan menengah di Indonesia akhir-akhir ini sangat signifikan turut andil dalam menguatkan perekonomian Nasional. Ini terbukti dari Data badan pusat statistik (BPS) dan Bekraf yang dirilis 2018 bahwasanya subsektor ekonomi kreatif yang meliputi kuliner, fesyen dan kriya ditahun 2016 berkontribusi pada Produk domestik bruto (PDB) sebesar Rp 922,59 triliun atau sekitar 7,44\% penyumbang perekonomian nasional Indonesia. Oleh karena itu, Pemerintah saat ini gencar memacu pertumbuhan perekonomian Nasional disektor UMKM ekonomi kreatif dengan melakukan beberapa kebijakan, seperti pemberian kemudahan akses modal, penurunan tarif pajak serta memperluas akses pemasaran. Kebijakan ini juga ikut mempengaruhi stake holder yang ada di Indonesia untuk dapat ikut berperan aktif guna mendukung tercapainya tujuan Pemerintah yaitu menciptakan pertumbuhan UMKM berbasis ekonomi kreatif di Indonesia sebagai penguat perekonomian nasional. Dalam hal ini peran serta pengemban institusi pendidikan dituntut dapat mengimplemetasikan secara nyata bidang Ilmunya sebagai penunjang berlangsungnya UMKM. Salah satu upaya itu diantaranya ialah mengadakan program pendampingan dan kerjasama Kemitraan.

Desa Pasar Banggi adalah desa yang mempunyai letak strategis, berada diantara Desa Tireman dan Desa Tritunggal desa ini terletak di Kecamatan Rembang Kabupaten Rembang Provinsi Jawa Tengah. Berada pada garis Lintang -6.706354 dan garis Bujur 111.387339. Desa Pasar Banggi memiliki luas wilayah 410,905 Ha dan mempunyai jarak $9 \mathrm{~km}$ dari pusat kota Rembang.

Desa Pasar Banggi memiliki potensi yang kurang diperhatikan oleh masyarakat, pemerintah desa maupun pemerintah daerah. Potensi yang terdapat di Desa Pasar Banggi diantaranya terdapat kelompok pengrajin pembuatan ikan asap yang belum disentrakan, pantai pasir putih yang bisa dijadikan tempat wisata, berbagai olahan hasil laut (rengginang, ikan asin, terasi). Kurangnya kepedulian dan kesadaran masyarakat akan adanya potensi yang besar ini menjadikan pentingnya peluang usaha yang ada di desa Pasar Banggi belum bisa dimaksimalkan. Potensi - potensi yang belum digali secara optimal tersebut diantaranya dari sektor kelautan dan perikanan adalah hasil olahan ikan.

Pengasapan ikan disini diproses cara membuat lubang-lubang besar ditanah dengan kedalaman tertentu berbentuk persegi panjang sebagai tungku tempat 
bahan bakarnya kemudian diatas lubang tungku tersebut ditaruh Angsang/Rak sebagai penyangga ikan waktu proses pengasapan berlangsung. Untuk bahan baku asap ini dihasilkan dari pembakaran Tempurung kelapa yang sampai saat ini dapat memberikan keunggulan Cita Rasa khas Produk ikan asap. Ada dua luaran hasil jika para pelaku usaha ini tetap bertahan dengan metode ini. Hasil yang pertama yaitu produk ikan asap dengan citarasa khasnya dan yang kedua adalah hasil residu bahan bakar asap yang berupa arang tempurung kelapa yang apabila dipasarkan akan menghasilkan nilai pendapatan tambahan bagi para pelaku UMKM.

Hasil prasurvei di Desa Pasar Banggi terdapat kelompok usaha pengrajin ikan asap yaitu Kelompok Usaha Olahan Ikan Laut Karya Mina. Kegiatan yang dilakukan oleh kelompok usaha tersebut masih sebatas pada pengasapan ikan (ikan asap) dengan kualitas olahan yang masih tradisional. Belum adanya alat pengasapan yang menggunakan teknologi ramah lingkungan dengan tetap mempertahankan kekhasannya yaitu aroma sangit yang dihasilkan dari pembakaran batok/tempurung kelapa. Karena pengolahan ikan asap yang belum menggunakan teknologi alat pengasap ikan yang ramah lingkungan ini menyebabkan pengolahan pengasapan ikan masih dilakukan secara tradisional dengan cara membuat galian tanah sesuai ukuran yang diinginkan dan menempatkan bahan bakar yang berupa batok/tempurung kelapa diatasnya kemudian diletakkan rak pemanggang ikan.Hal ini akan sangat berpengaruh terhadap produksi dan kualitas ikan asap, karena dengan proses pengasapan seperti itu kurang higienis, karena model pengasapan masih ditempat terbuka dan menempel dengan tanah. Sedangkan pengasapan yang dilakukan di tempat terbuka membuat asap menyebar kemana- mana yang dapat mengganggu polusi udara dan kenyamanan masyarakat setempat. Hal ini dapat dilihat dari gambar dibawah ini:

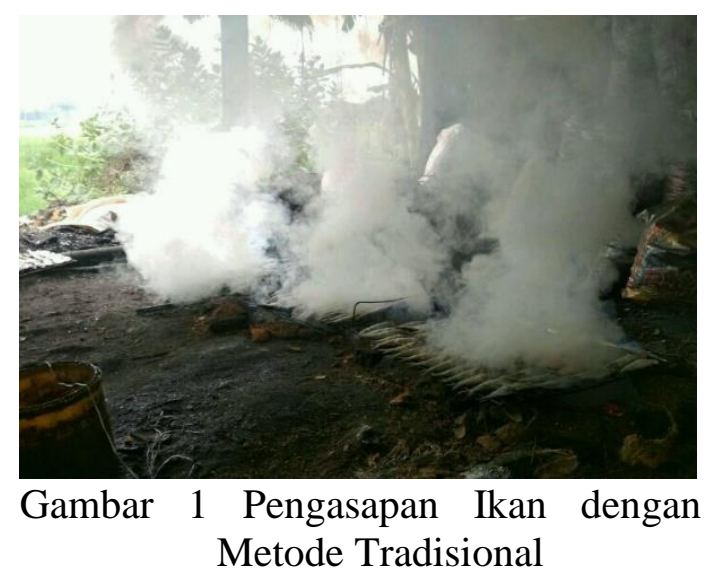




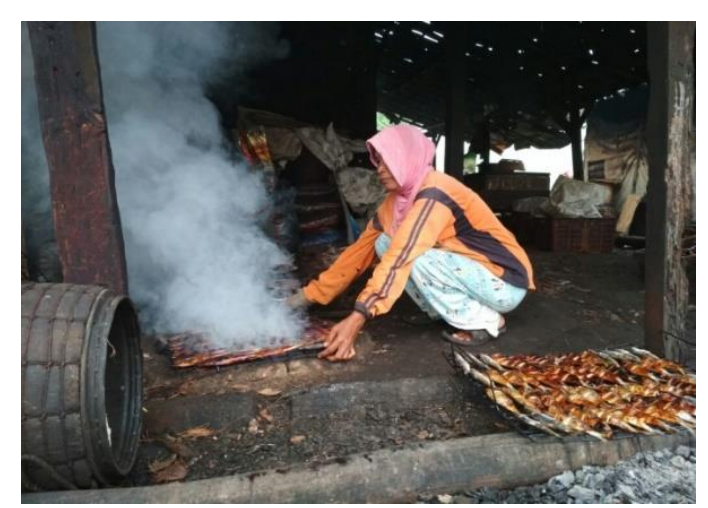

Gambar 1 Pengasapan Ikan dengan Metode Tradisional

Alat pengasapan ikan ramah lingkungan ini memungkinkan masyarakat kelompok pengrajin ikan asap dapat melakukan proses produksi setiap hari tanpa khawatir mengganggu kenyamanan masyarakat sekitar dan hasilnya juga lebih higienis. Alat pengasap ikan ramah lingkungan ini berfungsi untuk mengasap ikan lebih higienis dan dapat mengurangi polusi udara yang dapat mengganggu kenyamanan lingkungan sekitar. Sehingga dengan adanya alat/mesin pemanggang ikan yang ramah lingkungan itu diharapkan produktivitas bisa ditingkatkan yang diharapkan akan dapat berimbas pada tingkat pendapatan masyarakat pengasap ikan sehingga kesejahteraan dapat tercapai. Rancangan model alat pengasap ikan ramah lingkungan ini dapat dilihat pada gambar dibawah ini:

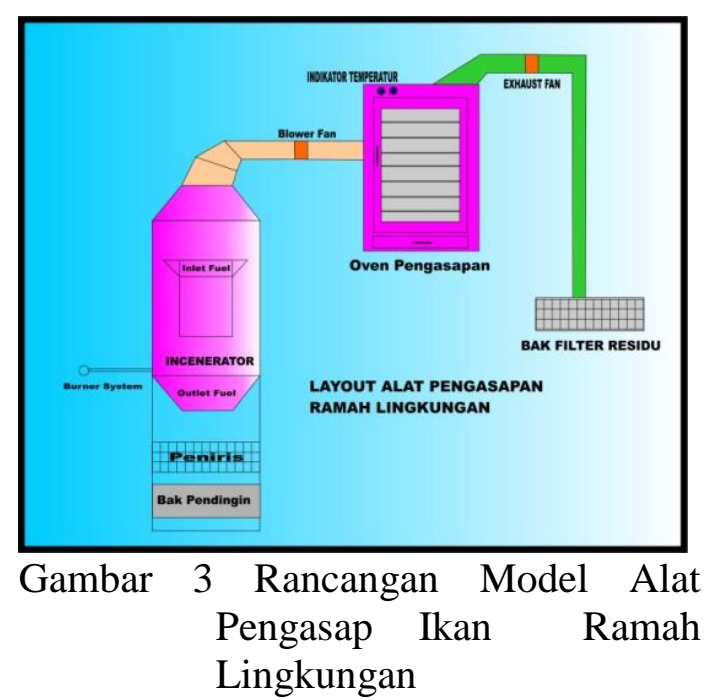

Disamping minimnya modal dan peralatan pengasap ikan, pengetahuan khususnya mengenai manajemen usaha dalam usaha pengasap ikan masih kurang baik, hal tersebut ditunjukkan dengan belum dilakukannya pembukuan kegiatan maupun keuangan dan pengelolaan keuangan secara baik. Kelompok usaha olahan ikan (ikan asap) di Desa Pasar Banggi masih belum mempunyai catatan pembukuan keuangan usaha dan pembukuan kegiatan secara baik.

1. Masalah Kapasitas produksi yang sampai saat ini $50-60 \mathrm{~kg} / \mathrm{hari}$ dirasa masih belum bisa maksimal jika dibandingkan dengan hasil ikan tangkapan mentahnya.

2. Teknik proses pengasapan tradisional cenderung kurang efektif karena ketika proses pengasapan berlangsung, pemanasan awal tungku memakan waktu agak lama (kurang lebih 30 menit) guna mendapatkan proses panas yang merata. Selain itu juga, asap yang dihasilkan 
dalam proses pembakaran ini banyak yang terbuang sia-sia karena tergantung arah angin ketika pembakaran terjadi.

3. Masalah kualitas produk hasil olahan ikan asap yang apabila di sesuaikan dengan standar foodgrade kurang layak apabila akan dipasarkan ke pangsa pasar yang lebih luas. Standar hieginisnya juga masih rendah karena masih dilakukan di tanah. Jadi kemungkinan ikan olahan kontak langsung dengan debu serta tanah masih tinggi.

4. Masalah akses pemasaran masih mengandalkan pedagang, pengepul atau dijual sendiri. permainan harga terjadi disini dan tidak bisa langsung masuk ke Franchaise toko oleh-oleh opo opo gitu..promosi melalui media sosial media online shop yang belum optimal.

5. Masalah manajemen usaha, seperti pengelolaan pembukuan keuangan, packaging dan difersifikasi produk yang kurang.

6. Efek samping metode pengolahan ikan asap tradisional ini timbulnya polusi asap ke lingkungan warga sekitar ketika proses produksi berlangsung. Hal ini sangat terasa sekali dampaknya bagi kesehatan. Sebagai contoh : membuat pedih mata, membuat sesak napas dan batuk, mengganggu jarak pandang, membuat cucian berbau asap, dan udara yang tidak segar lagi. Bila ini berlangsung terus menerus dan tidak ada solusi perbaikan dikhawatirkan bisa menurunkan kualitas hidup warganya

\section{METODE PEMECAHAN MASALAH}

Metode pendekatan yang dilakukan oleh Tim untuk menyelesaikan permasalahan mitra adalah:

1. Melakukan sosialisasi kepada pengolah ikan mengenai pentingnya/ manfaat adanya kelompok dan jejaring pengolah ikan di Desa Pasar Banggi Kecamatan Rembang Kabupaten Rembang.

2. Memfasilitasi teknologi produksi dengan alat pengasap ikan. Alat pengasap ikan ini berfungsi untuk mengasap ikan yang ramah lingkungan, sehingga asap dari bahan bakar tempurung kelapa tidak menyebar ke rumah warga setempat secara berlebihan. Alat pengasap ikan ini juga lebih higienis dalam prosesnya karena tidak bersentuhan langsung dengan tanah seperti yang dilakukan oleh para pengasap ikan jauh sebelum adanya alat ini. Alat pengasap ikan ini mempunyai banyak manfaat selain terkait dengan kualitas dan higienitas, residu/sisa dari pembakaran tempurung kelapa bisa menjadi arang yang mempunyai nilai jual kembali, dan sisa dari limbah air pengasapan ikan ini bisa menjadi pupuk cair yang bisa termanfaatkan untuk pertanian atau untuk pupuk tanaman. Diharapkan akan 
dapat berimbas pada tingkat pendapatan masyarakat pengasap ikan sehingga kesejahteraan dapat tercapai. Produksi juga tetap terjaga kualitasnya, sehingga produktivitas bisa ditingkatkan.

\section{Prosedur Kerja}

\section{Persiapan}

Tahap awal dalam pelaksanaan Program Kemitraan Masyarakat STIE YPPI Rembang dengan melakukan survei pendahuluan ke lokasi/daerah mitra. Survei dilakukan untuk mengetahui permasalahan mitra dan solusi bersama. Setelah tahap survei kemudian dilakukan rekruitmen calon peserta penyuluhan dan pelatihan di Desa Pasar Banggi Kecamatan Rembang Kabupaten Rembang. Pengolah ikan yang memenuhi kriteria yang telah ditetapkan oleh pelaksana, maka yang bersangkutan berhak ikut menjadi peserta pelatihan PKM STIE YPPI Rembang. Peserta yang dimaksud adalah pengolah ikan asap yang merintis usaha.

\section{Pelaksanaan}

Setelah diperoleh peserta penyuluhan dan pelatihan PKM STIE YPPI Rembang, maka dilakukan penyuluhan tentang pentingnya/manfaat kelompok bagi pengolah ikan asap yang dilanjutkan dengan memperkuat peran kelompok.

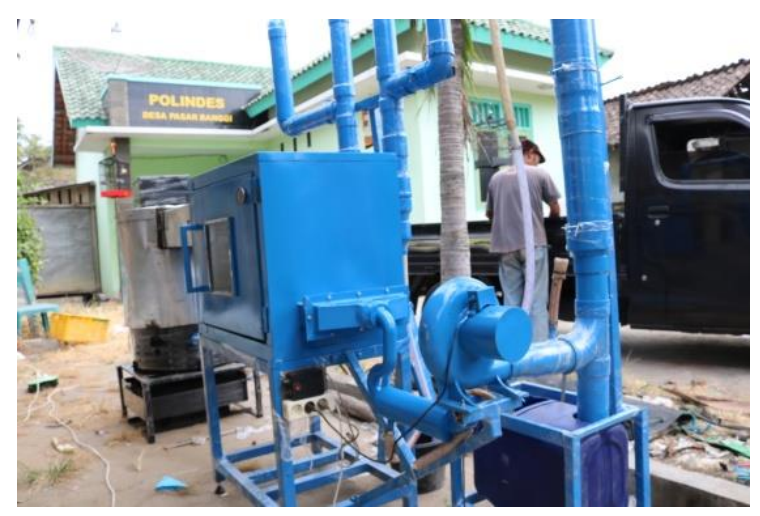

Gambar 4 Alat Pengasap Ikan

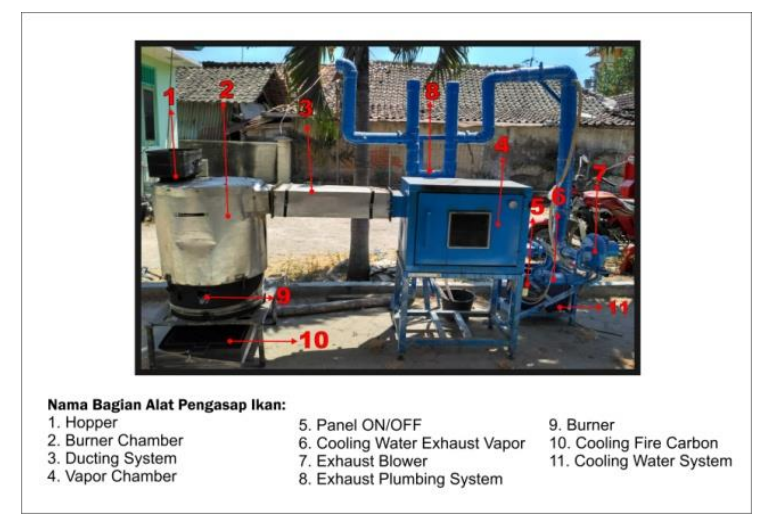

Gambar 5 Alat Pengasap Ikan

\section{Evaluasi}

Evaluasi dilaksanakan untuk mengetahui pelaksanaan Program Kemitraan Masyarakat (PKM) berjalan dengan lancar. Evaluasi dilaksanakan dengan cara melihat apakah materi pelatihan yang diberikan yaitu berupa pelatihan pemasaran (pemanfaatan teknologi), dalam peningkatan kualitas produksi serta manajemen usaha dan administrasi keuangan bisa dipahami, dimengerti, dipraktekkan dan dilaksanakan oleh kelompok pengolah ikan di Desa Pasar Banggi. 


\section{HASIL}

Kegiatan Program Kemitraan Masyarakat (PKM) yang diusulkan oleh STIE YPPI Rembang akan memiliki target luaran yang dihasilkan berupa terciptanya perancangan dan penerapan alat pengasap ikan, yang tujuannya dapat digunakan untuk proses pengasapan ikan agar lebih higienis dan ramah lingkungan dengan tetap mempertimbangan ciri khas ikan asap. Dengan penerapan alat pengasap ikan ini kualitas dan kapasitas produksi diharapkan dapat meningkat.

Adapun luaran dari PKM sebagai berikut:

1. Disosialisakannya alat tepat guna berupa Incenerator Machine untuk mengatasi permasalahan yang saat ini sangat urgent yaitu polusi asap yang bersumber pada teknik pengasapan tradisional.

2. Dibuatnya alat pendinginan arang batok kelapa/tempurung kelapa.

3. Dibuatnya Alat tepat guna berupa Oven Pemanggang untuk memperoleh hasil produk olahan yang lebih Hiegienis.

4. Dibuatnya alat penampung limbah dari residu pengasapan.

5. Bertambahnya pengetahuan mitra tentang proses pengerjaan/ pembuatan ikan asap metode dingin serta mendapatkan satu paket teknologi terintegrasi alat pengasap dingin.

6. Adanya pelatihan manajemen kewirausahaan bagi para warga kelompok UKM.

\section{PEMBAHASAN}

Metode pelaksanaan dalam usaha memberikan solusi pada permasalahan kelompok usaha pengasapan ikan ini melalui tahapan survei di lokasi Desa Pasar Banggi, Kecamatan Rembang, Kabupaten Rembang sebagai salah satu sentra penghasil produk ikan asap.

1. Survei di kelompok usaha ikan asap UKM Karya Mina Desa Pasar Banggi Kec. Rembang Kab.Rembang. Survei ini dilakukan untuk mengetahui berbagai persoalan yang dihadapi oleh usaha mikro ikan asap dalam pengasapan ikan. Berikut ini beberapa hasil indentifikasi permasalahan yang ada di kelompok usaha ikan asap antara lain:

a. Peralatan produksi yang masih menggunakan sistem tradisional.

b. Kapasitas produksi yang belum seimbang dengan jumlah hasil ikan tangkapan.

c. Tingkat hiegienitas ikan asap yang belum layak menurut standar makanan olahan (SNI 2527.1 2009)

d. Kemampuan manajemen dan sistem pemasaran yang belum optimal. 
e. Kemampuan pendanaan oleh para industri industri kecil ikan asap.

2. Merencanakan Alat Pengasap ikan yang ramah lingkungan. Perencanaan alat pengasap ikan yang ramah lingkungan ini didasarkan pada hasil survei dan wawancara dengan kelompok UKM ikan asap Desa Pasar Banggi Kecamatan Rembang Kabupaten Rembang yang dihasilkan perencanaan alat sbb:

a. Proses pengasapan ikan tidak lagi menggunakan sistem tradisional, tetapi memanfaatkan penggunaan teknologi alat pengasapan ikan yang ramah lingkungan dan higienis.

b. Alat berbahan stainless steel untuk keawetan dan kemudahan perawatan.

c. Bahan:

Untuk pembuatan alat Incenerator, pendingin arang tempurung kelapa, oven pengasapan, alat penampung residu pengasapan diperlukan bahan diantaranya:

- Besi sheet plate tebal $0.7 \mathrm{~mm}$

- Besi stainless steel sheet plate tebal $0.7 \mathrm{~mm}$

- Ducting

- Besi Siku 4x4cm

- Besi Hollow 2x4cm tebal $1.8 \mathrm{~mm}$

- $\quad$ Kabel NYM 2.5mm

- Wiremesh $4 \times 4 \mathrm{~cm}$ d. Dimensi tak lebih dari $100 \mathrm{x}$ 100x100 cm sesuai kesepakatan dan kemudahan penempatan alat.

e. Kapasitas produksi mencapai $30 \mathrm{~kg}$ / unit mesin.

f. Alat yang diperlukan untuk mendukung realisasi penunjang mesin tersebut antara lain : Termostat/Termometer, pematik, exhaust fan, Blower, burner gas elpiji, pompa sirkulasi air, stopwatch.

3. Rancangan Pembuatan Alat. Langkah awal yang dilakukan untuk pembuatan alat ini adalah perancangan dan pembuatan mesin Incenerator, alat pendingin arang, mesin oven pengasapan, alat penampung residu pengasapansupaya dapat dirangkai menjadi satu unit perangkat mesin yang saling berkaitan rangkaian proses operasionalnya. Waktu perancangan dan pembuatan 1 unit alat ini ditargetkan selama satu setengah bulan.

Selanjutnya dilakukan proses perangkaian unit mesin tersebut di Desa Pasar Banggi Kecamatan Rembang Kabupaten Rembang tempat para pelaku UKM melaksanakan proses produksi ikan asap.

Kemudian dilakukan proses uji coba unit mesin dengan para warga pelaku 
UKM yang meliputi pelatihan cara penggunaan mesin dan perawatan mesin.

4. Target Capaian Dalam Pembuatan Alat Target yang ingin dicapai dari pembuatan 1 unit alat pengolahan ikan asap ini ialah:

a. Merancang dan membuat alat tepat guna dan mesin pengolahan ikan asap yang ramah lingkungan

b. Mendapatkan produk olahan ikan asap yang Hiegienis.

c. Membantu mempercepat proses pengolahan ikan asap yang di targetkan membutuhkan waktu 10 menit 1 kali proses.dibanding yang saat ini membutuhkan waktu 15 menit dan setengah jam dalam durasi pembakaran tempurung kelapa.

d. Melatih para warga untuk bekerja profesional dengan alat yang sederhana.

5. Sosialisasi dan Pelatihan Sosialisasi dan Pelatihan dilakukan untuk memberikan pemahaman kepada mitra tentang prototipe dan prinsip kerja alat pengasap ikan ramah lingkungan. Sosialisasi dan Pelatihan dilakukan selama 1 minggu dengan cara berkunjung ke tempat usaha mitra dan memberikan pengarahan tentang pengoperasian dan pemeliharaan alat pengasap ikan. Dalam masa ini juga dimaksudkan untuk mencari masukan- masukan dari mitra tentang penerapan alat pengasap ikan.

6. Melakukan pelatihan manajemen usaha ikan asap dan kewirausahaan, yang mencakup: motivasi berwirausaha, inovasi dan kreativitas, pengelolaan keuangan, manajemen pemasaran dan ecommerce, serta diteruskan dengan pendampingan usaha.

7. Mengajak dan mendorong Pemerintah Kabupaten Rembang, Dinas Perindustrian, Perdagangan, Koperasi, dan UKM (Dinindagkop dan UKM) serta Dinas Kelautan dan Perikanan untuk lebih memperhatikan pengrajin ikan asap diDesa Pasar Banggi Kecamatan Rembang Kabupaten Rembang sebagai salah satu aset Desa Pasar Banggi Kecamatan Rembang Kabupaten Rembang.

Komponen yang dievaluasi dengan penerapan alat pengasap ikan pada usaha ikan asap ini adalah:

1. Aspek Produksi:

a. Hasil pengasapan ikan lebih higienis dibandingkan dengan pengasapan dengan menggunakan sistem tradisional.

b. Kemampuan mesin dalam pengasapan ikan dengan 
membandingkan pengasapan ikan secara tradisional.

c. Kemampuan/kapasitas pengasapan ikan mesin/alat pengasapan ikan dengan membandingkan dengan pengasapan sistem tradisional.

d. Kualitas ikan asap hasil produksi dengan menggunakan alat ini dan dengan menggunakan sistem tradisional.

e. Meminimalkan asap yang disebabkan dari pengasapan ikan secara konvensional/tradisioanal.

2. Aspek Manajemen:

a. tingkat kepuasan UKM dengan penerapan alat pengasap ikan ramah lingkungan.

b. Tingkat pemahaman pekerja tentang operasional dan pemeliharaan alat pengasap ikan ramah lingkungan.

c. Evaluasi pendapatan UKM dengan adanya penerapan alat pengasap ikan ramah lingkungan.

Luaran yang dihasilkan pada Program Kemitraan Masyarakat ini adalahsebagai berikut:

1. Perubahan mindset para pengrajin terasi dalam hal memanfaatkan kelompokpengrajin terasi dan jejaring serta mendukung ikon sebagai Desa Wisata Religi yang berorientasi pada keuntungan (profit oriented).
2. Artikel Jurnal Ilmiah.

Adanya kartu nama, blog, catatan keuangan (pembukuan) dan spanduk (banner).

\section{KESIMPULAN}

1. Pelaksanaan program kemitraan masyarakat mencapai keberhasilan tidak terlepas dari dukungan dan kerjasama dari pihak mitra, keberhasilan ini terlihat dari pelatihan pengolahan ikan dengan menggunakan alat pengasap ikan, pengolahan ikan menjadi makanan siap saji dan tata cara produksi pangan yang baik dapat berjalan sesuai prosedur.

2. Pelaksanaan program mampu menghasilakan luaran-luaran yang diharapkan oleh program pengabdian kepada masyarakat ini, kecuali ijin pirt masih harus diurus oleh mitra karena perlu tahapan-tahapan administrasi melalui proses pendaftaran yang dengan beberapa syarat yang harus dipenuhi.

3. Pengasap ikan tradisional belum mau menerima cara baru karena belum tahu contoh cara produksi yang lebih sehat, dan kejelasan pasar ikan asap yang lebih berkualitas.

\section{SARAN}

Dalam rangka meningkatkan transfer iptek kepada masyarakat kelompok usaha 
kecil hendaknya kegiatan pengabdian pada masyarakat digalakan sehingga kemampuan masyarakat dapat ditingkatkan sekaligus dapat meningkatkan pendapatan masyarakat serta dapat membuka lapangan kerja bagi masyarakat lain.

\section{UCAPAN TERIMA KASIH}

1. Dirjen Penguatan Riset dan Pengembangan Kementerian Riset, Teknologi danPendidikan Tinggi yang telah mendanai kegiatan Program Kemitraan Masyarakat (PKM) ini.

2. Drs. H. Muhammad Asrori, M.Si., Ketua STIE YPPI Rembang.

3. Anik Nurhidayati, SE., MM., Ketua LPPM STIE YPPI Rembang.

\section{DAFTAR PUSTAKA}

Andriyono, S., Thajaningsih, W., Agustono, A., Masithah, E. D., tri Pursetyo, K., Abdillah, A. A., \& Pramono, H. (2015). Aplikasi Teknologi Asap Cair dalam Pengolahan dan Pengawetan Produk Perikanan di Pulau Mandangin [Technology Application of Liquid Smoke in Processing and Preservation of Fishery Products in The Mandangin Island]. Jurnal Ilmiah Perikanan dan Kelautan, 7(1), 1-6.
Dinas Kelautan dan Perikanan Kabupaten Rembang, 2016.

Fuad, M. A. Z. (2019). Peningkatan Produksi dan Pengembangan Industri Rumah Tangga (IRT) Ikan Asap di Desa Banyuurip-UjungpangkahGresik. J-Dinamika, 4(1).

Harlina, H., \& Hadijah, S. (2017). Pkm Kelompok Nelayan Pengolah Ikan Pari Asap. JATI EMAS (Jurnal Aplikasi Teknik dan Pengabdian Masyarakat), 1(2), 73-77.

Rembang, B. K. (2017). Kabupaten Rembang Dalam Angka 2017.

Sebayang, N. (2002). Penerapan teknologi pengasapan ikan bagi masyarakat nelayan. Jurnal Pengabdian Kepada Masyarakat, 8(28), 25-34.

Sumartini, S., Syarifuddin, M., \& Swastawati, F. (2013). Penerapan Tungku Sierra Leone Sebagai Alternatif Pengentasan Kemiskinan Pada Sentra Pengasapan Mangunharjo Semarang (The Application of Sierra Leone Furnace as an Alternative to Poverty Reduction at the Center of Smoking Mangunharjo Semarang). SAINTEK PERIKANAN: Indonesian Journal of Fisheries Science and Technology, 9(1), 1-6. 